\title{
Oxygen as a Regulator of Serine Dehydratase (SerDH) Gene Expression.
}

\author{
A. Samoylenko' ${ }^{1}$ N. Tepliuk ${ }^{2}$, M. Obolenskaya², T. Kietzmann ${ }^{3}$
}

\author{
${ }^{1}$ Palladin Institute of Biochemistry of the NASU \\ 9 Leontovych Str., Kyiv, 01601, Ukraine \\ ${ }^{2}$ Institute of Molecular Biology and Genetics of the NASU \\ 150 Academician Zabolotny Str., Kyiv, 03143, Ukraine \\ ${ }^{3}$ Technical University of Kaiserslautern \\ 54 Erwin-Schrodinger-Stra?e, Kaiserslautern, 67663, Germany \\ samoylenko@biochem.kiev.ua
}

\begin{abstract}
An oxygen gradient is formed in the liver due to the unidirectional bloodflow from the portal vein and hepatic artery to the central vein and due to the oxygen-consuming metabolic processes of the cells along the sinusoid. This gradient appears to be one of the major factors responsible for differential expression of a number of genes between periportal and perivenous zones of liver sinusoid. The serine dehydratase (SerDH) gene is predominantly expressed in the hepatocytes of periportal zone. Northern blot analysis and transfections with SerDH promoter luciferase constructs containing SerDH promoter $(-2303 \ldots+55$ bp) upstream of the Firefly luciferase gene demonstrated that the SerDH expression was higher under normoxia $\left(16 \% \mathrm{O}_{2}\right)$ as compared to hypoxia $\left(8 \% \mathrm{O}_{2}\right)$. Four putative normoxia responsive elements (NRE) were found in the SerDH promoter (NRE-1, NRE-2, NRE-3, NRE-4). To identify which of these elements is functional in hepatocytes, several plasmids containing 6 copies of putative SerDH NRE's upstream of the SV40 promoter and the Firefly luciferase gene were constructed. It was found that NRE-2 in both HeLa and HepG2 cells as well as NRE-1 in HeLa cells were responsible for the $\mathrm{O}_{2}$-dependent SerDH gene expression.
\end{abstract}

Keywords: serine dehydratase gene, transcription regulation, reporter gene, luciferase, hepatocytes, normoxia

Introduction. An oxygen gradient is formed in the liver due to the unidirectional bloodflow. Oxygen partial tension (free concentration) equals about 60-65 $\mathrm{mm}$ $\mathrm{Hg}$ in the periportal blood and falls to about $30-35 \mathrm{~mm}$ $\mathrm{Hg}$ in the perivenous blood. This gradient in $\mathrm{O}_{2}$ tension appears to play a key role in the differential expression of a number of genes between the more aerobic

\footnotetext{
(C) A. SAMOYLENKO, N. TEPLIUK, M. OBOLENSKAYA, T. KIETZMANN, 2007
}

periportal zone and less aerobic perivenous zone of liver sinusoid [1].

It has been shown that promoters of most genes induced by hypoxia contain a specific $\mathrm{O}_{2}$ responsive sequence, named the hypoxia response element (HRE) [2]. This sequence can be bound by several related transcription factors known as hypoxia-inducible factors (HIF), among which HIF-1 is studied the most. HIF-1 is a dimer of HIF- $1 \alpha$ and HIF-1 $\beta$, both belonging to the basic helix-loop-helix (bHLH) PAS (Per-ARNT-Sim) 
transcription factor family. While HIF-1 $\beta$ was found to be a constitutional protein, HIF-1 $\alpha$ protein levels were oxygen-dependent. Although hypoxia may have insignificant effect on the HIF-1 $\alpha$ mRNA expression, the major regulation appears to occur posttranslationally on the level of protein stabilization. Under normoxia two proline residues ( $\mathrm{P} 402$ and $\mathrm{P} 564$ ) within the $\mathrm{O}_{2}$-dependent degradation domain of HIF- $1 \alpha$ are subject to hydroxylation by a new family of prolyl hydroxylases. The hydroxylation enables the binding of the von Hippel-Lindau (VHL) tumor suppressor protein, a component of an E3 ubiquitin ligase complex that targets the HIF $\alpha$-subunits for degradation by the ubiquitin-proteasome pathway.

While the molecular mechanisms of the hypoxia-dependent gene regulation are well characterized, the mechanisms, regulatory transcription factors, and the DNA responsive elements required for normoxia-dependent gene induction are poorly known [3-5]. It was the aim of the present study to characterize the oxygen-dependent expression of serine dehydratase (SerDH) gene, one of the genes upregulated in the more aerobic periportal zone as compared to the perivenous zone of liver sinusoid, and to identify promoter elements responsible for this regulation.

L-serine dehydratase (L-serine ammonia-lyase, EC 4.2.1.13) is an enzyme, catalyzing the pyridoxal phosphate-dependent deamination of serine to produce pyruvate. This enzyme catalyzes the conversion of L-threonine to $\alpha$-ketobutyrate by the same mechanism and is identical to L-threonine dehydratase (EC 4.2.1.16). It is a homodimeric protein having a 327 amino acid subunit with molecular weight of $34 \mathrm{kDa}$ [6]. SerDH is expressed in liver predominantly and to a lesser extent - in kidney. Its expression is activated by glucagon and glucocorticoids and repressed by insulin [7], while oxygen-dependent regulation of SerDH has not been investigated yet.

Materials and Methods. The isolation of primary rat hepatocytes from liver was performed at sterile conditions by the method of collagenase perfusion as described in [8]. Hepatocytes were cultured in medium M 199 (Gibco, Eggenstein, Germany) in the presence of dexamethasone $(10 \mu \mathrm{M})$, insulin $(1 \mathrm{nM})$ and (in the course of the first $4 \mathrm{~h}$ after plating) $4 \%$ fetal calf serum (FCS). HeLa and hepatoma HepG2 cells were cultured in the MEM medium (PAA Laboratories, Austria) containing $10 \%$ FCS. The cells were cultured in $\mathrm{CO}_{2}$ incubator Cytoperm 8080 (Heraeus, Hanau, Germany) at $37^{\circ} \mathrm{C}$ in humidified atmosphere containing $8 \% \mathrm{O}_{2}$ (mild hypoxia) or $16 \% \mathrm{O}_{2}$ (normoxia), $5 \% \mathrm{CO}_{2}$ and $87 \%$ or $79 \% \mathrm{~N}_{2}$, respectively. Taking into account oxygen diffusion through culture medium, oxygen concentrations in $\mathrm{CO}_{2}$ incubator correspond to the physiological oxygen concentrations on the surface of perivenous and periportal hepatocytes [1].

To construct the plasmids pGL3SerDH-2303, pGL3SerDH-2128, pG13SerDH-937, pG13SerDH-471, and pGl3PCK-493, the vector pGL3 basic (4818 b.p.) (Promega, Mannheim, Germany), containing the Firefly luciferase (Luc) gene as a reporter to estimate the promoter activity, was used. The corresponding regions of SerDH promoter were cloned in the polylinker of pG13 basic. The plasmids pG13-SerDH-NRE1, pGl3-SerDH-NRE2, pG13-SerDH-NRE3, and pG13-SerDH-NRE4 were constructed using the vector pGL3 promoter (Promega), in the polylinker of which the corresponding oligonucleotides were cloned in front of SV40 promoter. The oligonucleotides containing six copies of the corresponding NRE elements were obtained from the NAPS company (Gottingen, Germany) and HPLC purified. Each repeating unit contained 9 b.p. of the corresponding NRE flanked by 3 b.p. at the 5?- and by 2 b.p. at the 3?-ends. The oligonucleotides also contained additional sequences which were necessary for technical reasons, namely, either the SpeI or SmaI restriction sites in the middle of the sequence for the identification of positive clones and both SacI and NheI sites at the ends. The construct pG13-Epo-HRE contained three copies of the HRE from the erythropoietin gene in front of pGl3 promoter and was already described [9]. E. coli K $12 \mathrm{DH} 5 \alpha$ and XL1-blue strains (Stratagene, Heidelberg, Germany) were transformed by electroporation. Plasmid DNA was isolated using JETstar Plasmid Purification System (Genomed, Bad Oeynhausen, Germany).

Primary rat hepatocytes $\left(1 \cdot 10^{6}\right.$ cells per $\varnothing 60 \mathrm{~mm}$ dish), HeLa and HepG2 cells (confluent cultures on $\varnothing$ $60 \mathrm{~mm}$ dishes) were transfected using calcium phosphate precipitation method with $2.5 \mu \mathrm{g}$ plasmid DNA, consisting of $500 \mathrm{ng}$ pRL-V40 (Promega) and $2 \mu \mathrm{g}$ Firefly luciferase reporter gene construct, as described 


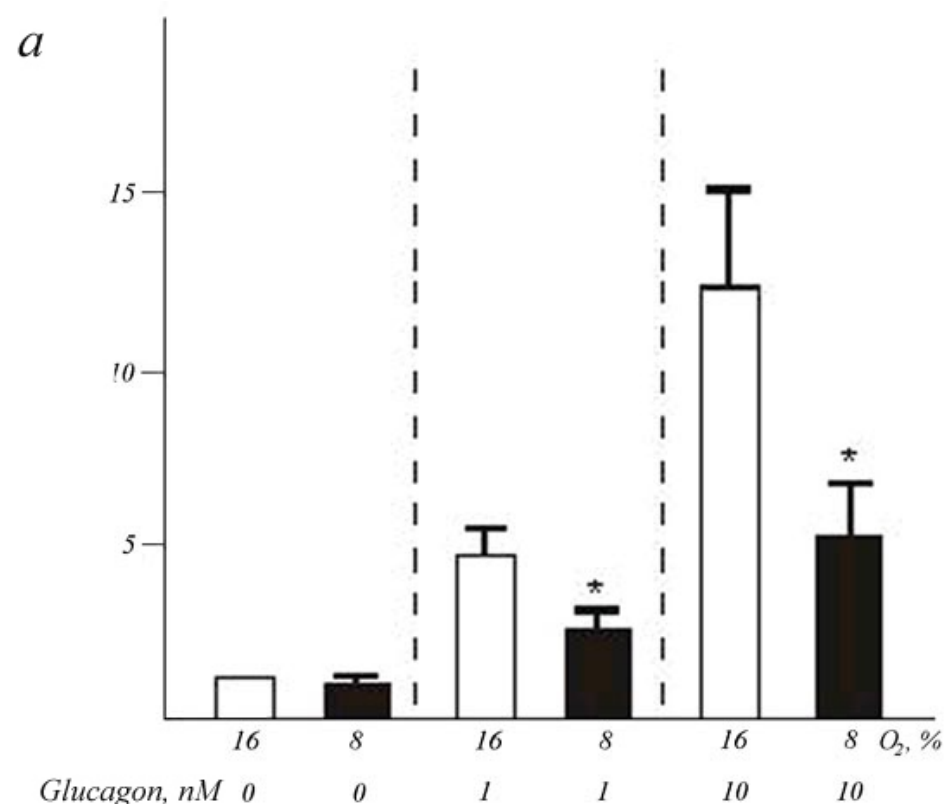

$b$

Glucagon, $n M$

$\mathrm{O}_{2}, \%$

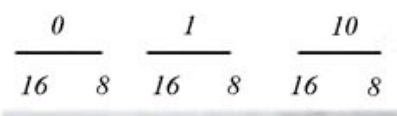

$\operatorname{SerDH} m R N A$

$\beta$-actin mRNA

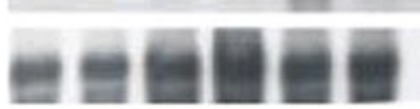

Fig. 1. Modulation of glucagon-dependent SerDH mRNA expression by oxygen in rat primary hepatocytes. Hepatocytes were first cultured for $24 \mathrm{~h}$ under normoxia $\left(16 \% \mathrm{O}_{2}\right)$. After $24 \mathrm{~h}$ the medium was changed and cells were further cultured for $24 \mathrm{~h}$ under normoxic or hypoxic $\left(8 \% \mathrm{O}_{2}\right)$ conditions. After $21 \mathrm{~h}$ cells were treated with the indicated concentrations of glucagon (ggn.). (A) The SerDH mRNA levels were measured by Northern blotting. The mRNA level under normoxia was set equal to 1 . Values are means \pm SEM of three independent culture experiments. Statistics, Student's t-test for paired values: * significant difference $8 \% \mathrm{O}_{2}$ vs. $16 \% \mathrm{O}_{2}, \mathrm{p} \leq 0.05$. (B) Representative Northern Blot. For Northern analysis $15 \mu \mathrm{g}$ total RNA were hybridized to digoxigenin-labelled SerDH and $\beta$-actin antisense RNA probes. Autoradiographic signals were obtained by chemiluminescence and scanned by videodensitometry. before [10]. Construct pRL-SV40, expressing Renilla luciferase gene under control of SV40 promoter, was used to control transfection efficiency. In every culture experiment, two dishes were transfected per measured point. After removal of the media $(4 \mathrm{~h}$ after transfection), cells were cultured at standard conditions without serum. After $24 \mathrm{~h}$, the medium was changed and cells were cultured for another $24 \mathrm{~h}$ either under hypoxia or normoxia. Cells were then washed twice with $0.9 \% \mathrm{NaCl}$ and incubated for 15 min on a rocking platform with $300 \mu$ of passive lysis buffer supplied with the Dual Luciferase Reporter Assay Kit (Promega). The lysate was then scraped from the plates, vortex-mixed, and centrifuged for $2 \mathrm{~min}$. From the supernatant, $20 \mu \mathrm{l}$ was assayed for Firefly luciferase activity in a luminometer Auto Lumat Plus LB 953 (Berthold, Pforzheim, Germany). After addition of 100 $\mu 1$ of Stop and Glo ${ }^{\mathrm{TM}}$ Reagent (Promega), which quenches the activity of Firefly luciferase, the Renilla luciferase activity was recorded again in a luminometer. Luciferase activity presented in figures was calculated as a ratio between intensities of Firefly and Renilla luciferase luminescence (normalized luminescence). Statistical analysis was performed as described in Legends to Figures.

Total RNA from hepatocytes was isolated using isothiocyanate method as described [11]. The detection of mRNA on Northern blots was performed after hybridization of $15 \mu \mathrm{g}$ total RNA with digoxigenin labeled SerDH or $\beta$-actin specific probes (DIG RNA Labeling Kit, Roche, Mannheim, Germany). Hybridization signals were visualized by chemiluminescence, and the videodensitometer (Biotec-Fischer, Reiskirchen, Germany) was used for quantification of these signals.

Results and Discussion. Induction of SerDH mRNA expression by glucagon and its modulation by oxygen.Primary rat hepatocytes were cultured for $24 \mathrm{~h}$ at standard conditions and then treated for $24 \mathrm{~h}$ under hypoxia $\left(8 \% \mathrm{O}_{2}\right)$ or normoxia $\left(16 \% \mathrm{O}_{2}\right)$ either with or 


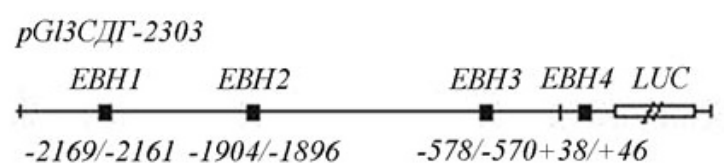

pGl3СДI-2128

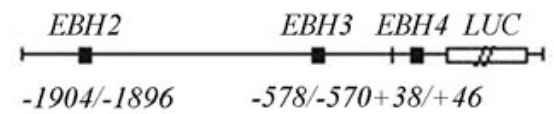

pGI3СДГ-937

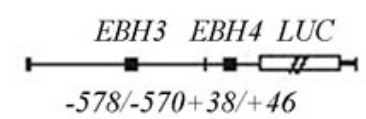

pGl3CДГ-471

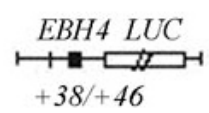

$\mathrm{O}_{2}, \%$ Luciferase activity, \%

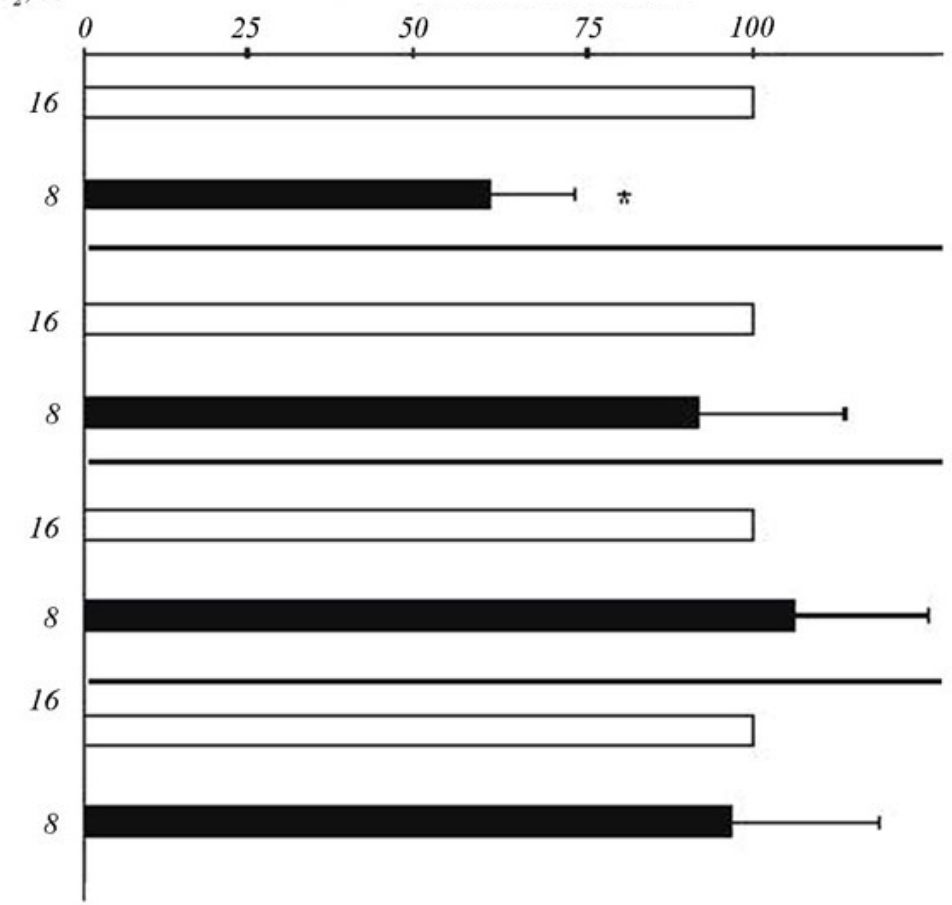

Fig. 2. Regulation of SerDH promoter Luc gene expression by oxygen. The hepatocytes were transiently transfected with the Luc gene constructs driven by a wild type -2303 b.p., -2128 b.p., -937 b.p. or -471 b.p. rat SerDH promoter (pG13SerDH-2303, pG13SerDH-2128, pG13SerDH-937, and pG13TAT-471). Hepatocytes were first cultured for $24 \mathrm{~h}$ under normoxia $\left(16 \% \mathrm{O}_{2}\right)$. After $24 \mathrm{~h}$ the medium was changed and cells were further cultured for $24 \mathrm{~h}$ under normoxic or hypoxic $\left(8 \% \mathrm{O}_{2}\right)$ conditions. In each experiment the percentage of Luc activity was determined relative to the corresponding $16 \% \mathrm{O}_{2}$ controls which were set equal to $100 \%$. The values represent means \pm SEM of six independent experiments. Statistics, Student's t-test for paired values: * significant difference $8 \% \mathrm{O}_{2}$ vs. $16 \% \mathrm{O}_{2}$, p $\leq 0.05$.

without addition of glucagon. In the absence of its inducer - glucagon, SerDH mRNA expression in primary rat hepatocytes was not detectable (Fig.1). It proves that normoxia alone is not a sufficient stimulus to induce SerDH expression. Indeed, the expression of gluconeogenic SerDH enzyme in vivo at standard conditions is undetectable. However, fasting, leading to secretion of glucagon, stimulates SerDH expression [7].

When the cells were treated for $3 \mathrm{~h}$ with $1 \mathrm{nM}$ glucagon, SerDH mRNA expression was induced app. 5-fold under normoxia and app. 2-fold under hypoxia. At a glucagon concentration of $10 \mathrm{nM}$ SerDH mRNA levels were further enhanced app. 12-fold under normoxia and app. 5-fold under hypoxia, thus, SerDH mRNA levels under normoxia were again app. 2.5-fold higher than SerDH mRNA levels under hypoxia. These results indicate that regardless of the presence of different glucagon concentrations, SerDH mRNA expression under hypoxia is much lower than under normoxia (Fig.1).

Localization of the normoxia responsive elements in the promoter of SerDH gene. To find out what sequences could be involved in the regulation of SerDH gene expression by oxygen, the SerDH promoter sequence was analyzed for similarities with the NRE of the phosphoenolpyruvate carboxykinase-1 (PCK-1) gene 5'-TTAGGTCAG-3' [4].

Sequence analysis of the rat SerDH promoter revealed that four putative NREs were present within the first 2303 b.p. of the promoter. All four potential normoxia response elements, namely, NRE-1, -2169/-2161, 5'-TGAGGACAG-3', NRE-2, -1904/-1896, 5'-TTATGTGAG-3', NRE-3, -578/-570, 5'-TTAGTCCAG-3', and NRE-4, +38/+46, 5'-CTAGATCAG-3', match the NRE of the PCK-1 gene in 7 out of 9 b.p. 
A 2303 b.p. fragment of the 5'-flanking region of rat SerDH gene was cloned in front of the luciferase gene in pG13-basic to generate pG13SerDH-2303. In primary rat hepatocytes transfected with pGI3SerDH-2303 Luc activity was induced maximally under normoxia and to only app. $60 \%$ under hypoxia (Fig.2).

The Luc activity in cells transfected with pGI3SerDH-2303 and treated with glucagon was not induced compared to the untreated control (unpublished data). These results are in line with other studies since both cAMP-regulatory elements (CRE-1 and CRE-2) of SerDH gene, potentially involved in the glucagon-dependent gene induction, are located app. 3500 b.p. upstream from the transcription initiation site, i.e. they are not present in the construct pGl3SerDH-2303 or the shorter constructs used in our experiments [12]. A CRE-1 located at -3528/-3521 of the SerDH gene is not involved directly in the gene activation by hormones whereas CRE-2 (-3538/-3531), adjacent to CRE-1 and bound by CREB (CRE binding protein), appears to be critical for cAMP and glucagon-dependent induction of SerDH expression [12].

To determine what region of the SerDH promoter could be responsible for the oxygen-dependent regulation of SerDH gene expression, primary rat hepatocytes were transfected with three serially deleted SerDH promoter luciferase gene constructs pG13SerDH-2128, pGl3SerDH-937, and pGl3SerDH-471 containing the first 2128 b.p., 937 b.p., and 471 b.p. of the SerDH promoter, respectively (Fig.2). Normoxia did not induce Luc activity in the cells transfected with either pG13SerDH-2128, pG13SerDH-937 or pGl3SerDH-471 indicating that NRE-2, NRE-3, and NRE-4 did not seem to be involved in the regulation of SerDH gene expression by normoxia.

These results demonstrated that the expression of the -2303 SerDH promoter Luc gene construct was induced by normoxia and the normoxia responsive region of SerDH was localized between -2128 and -2303 b.p. of the SerDH promoter.

Biological activity of the potential SerDH-specific NREs under heterological conditions. Since hypoxia responsive elements from erythropoietin and other hypoxia-regulated genes could act as transcriptional enhancers when cloned in front of an independent pro- moter and a reporter gene, the role of potential NREs from SerDH promoter in the normoxia-dependent gene regulation was investigated using these elements as enhancers, regulating expression of the reporter luciferase gene. The 90 b.p. oligonucleotides containing 6 copies either of NRE-1, NRE-2, NRE-3 or NRE-4 from the SerDH promoter were cloned in front of the SV40 promoter and the luciferase gene in pGl3-prom to generate pG13-SerDH-NRE1, pG13-SerDH-NRE2, pG13-SerDH-NRE3, and pG13-SerDH-NRE4. When primary rat hepatocytes were transfected with these constructs, neither of them was expressed differentially under normoxia or hypoxia. However, in HepG2 cells the construct pGl3-SerDH-NRE2 was activated by normoxia in about $40 \%$, while the others displayed the same levels of Luc activity under normoxia and hypoxia. In HeLa cells the expression of two out of four constructs, pGl3-SerDH-NRE1 and pG13-SerDH-NRE2, was activated by normoxia in about $30 \%$ (Fig.3). Luc activity in the cells transfected with the hypoxia-inducible pGl3-Epo-HRE construct [9] as a control was significantly higher in the cells cultured under hypoxia for all three cell types investigated (Fig.3).

These results indicate that some potential SerDH NREs are more active in immortalized cells. It is well known that intratumoral hypoxia is one of the driving forces in cancer progression and a lot of genes involved in survival, angiogenesis, and metastases formation are induced by hypoxia [13-14]. On the other hand, some pro-oncogenic proteins (e.g. plasminogen activators) are induced by normoxia [15-16]. Therefore, hypothetical activation of factors stimulated by normoxia because of genetic changes in the process of carcinogenesis might activate these genes even under normoxia.

The majority of genes modulated by $\mathrm{O}_{2}$ have been shown to be induced by hypoxia. Though several genes have been found to be positively modulated by normoxia [1], little is known about possible normoxia regulatory elements as well as corresponding transcription factors mediating this modulation and a general idea has not been presented. In the current study it was shown that SerDH promoter sequences homologous to the previously identified NRE of the PCK-1 gene [4] were involved in the normoxia-dependent gene regula- 
pGl3-СДI-EBHI

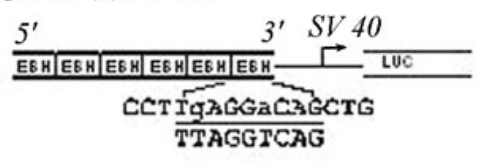

pGl3-CДI-EBH2

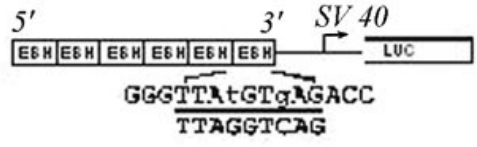

pGI3-СДГ-EBH3

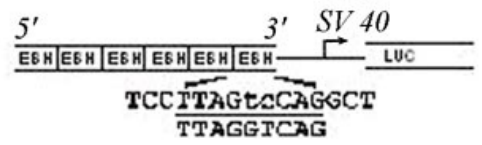

pGl3-СДГ-ЕВН4

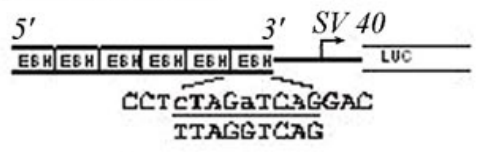

pGI3-EПO-EBI

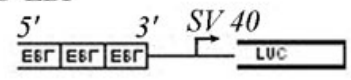

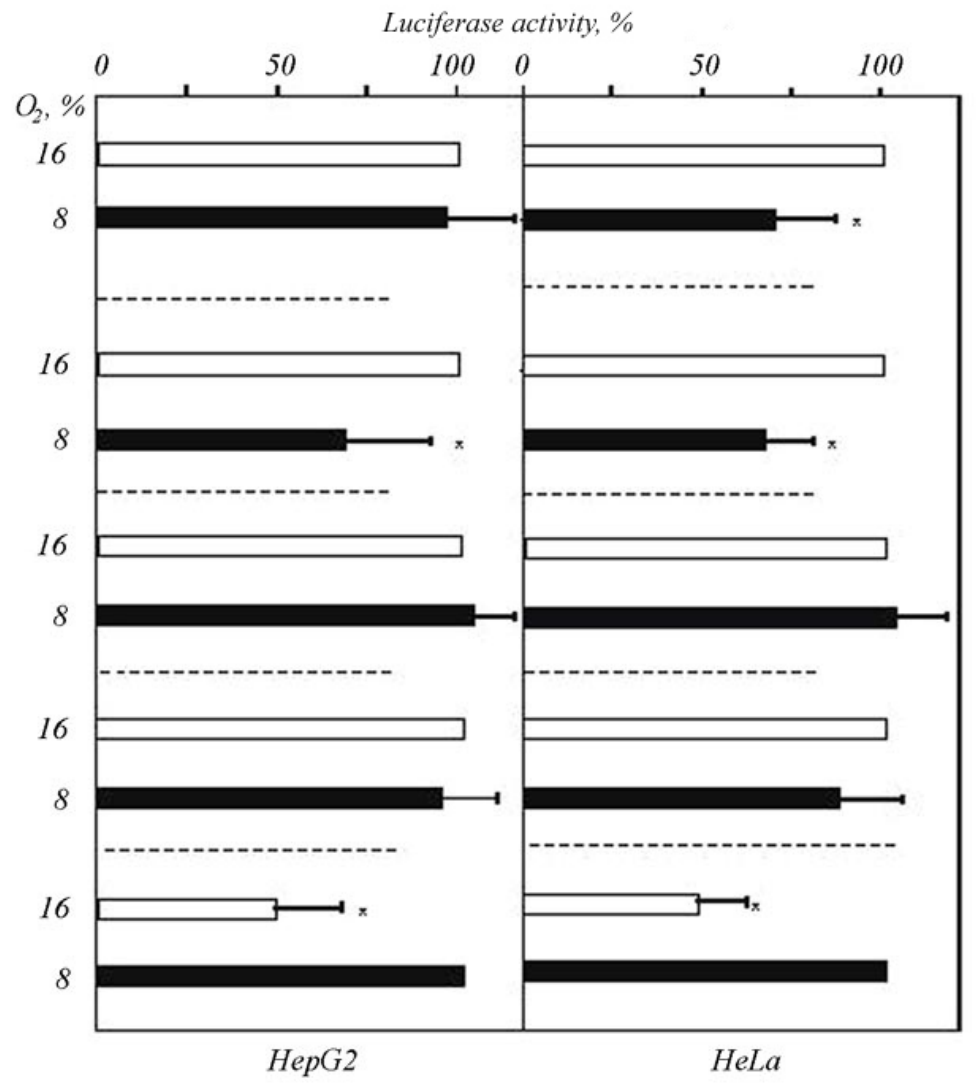

Fig. 3. Oxygen-dependent expression of pGl3-SerDH-NRE Luc constructs in HepG2 and HeLa cells. HepG2 and HeLa cells were transiently transfected with the Luc gene constructs pGl3-SerDH-NRE1, pGl3-SerDH-NRE2, pGl3-SerDH-NRE3, pG13-SerDH-NRE4, and pGl3-Epo-HRE. After $24 \mathrm{~h}$ medium was changed and the cells were cultured for $24 \mathrm{~h}$ under normoxic $\left(16 \% \mathrm{O}_{2}\right)$ or hypoxic $\left(8 \% \mathrm{O}_{2}\right)$ conditions. In each experiment the percentage of Luc activity was determined relative to the corresponding $16 \% \mathrm{O}_{2}$ controls (for pGl3-Epo-HRE corresponding to the $8 \%$ control) which were set equal to $100 \%$. The values represent means \pm SEM of three independent experiments. Statistics, Student's t-test for paired values: * significant difference $8 \% \mathrm{O}_{2}$ vs. $16 \% \mathrm{O}_{2}, \mathrm{p} \leq 0.05$. Sequences shown in the upper strand correspond to the sequences of the SerDH gene. The NRE sequences are underlined. Sequences shown in the lower strand correspond to the PCK-1 NRE. The nucleotides different for SerDH NRE and PCK-1 NRE are shown in lower case letters.

tion. On the other hand, in the human glutathione peroxidase (GPX) gene two similar 13 b.p. oxygen responsive elements were found to bind disparate proteins and to confer normoxia-dependent induction of GPX gene expression in human cardiomyocytes $[3,5]$. The sequences of the oxygen responsive elements from the GPX gene are not similar to the NRE sequences identified in our experiments. It might be also speculated that higher gene expression under normoxia as shown in our study could be due to an inhibitory effect of HIF-1 under hypoxia. However, HIF-1 usually acts as an activator and the role of HIF-1 as transcriptional inhibitor was demonstrated only for few genes so far [17]. This mechanism does not appear to account for SerDH modulation by oxygen since its promoter con- tains no complete 8 b.p. HRE in the 5?-flanking region. The ability of NREs, described in our study, to function in various cell types and in different promoters indicates that these promoter elements are not specific for SerDH gene only.

In the present study the $\mathrm{O}_{2}$-dependent expression of SerDH mRNA and the $\mathrm{O}_{2}$-dependent regulation of SerDH promoter activity were demonstrated. Both SerDH mRNA and SerDH promoter-driven luciferase reporter gene stimulation by normoxia $\left(16 \% \mathrm{O}_{2}\right)$ as compared to mild hypoxia $\left(8 \% \mathrm{O}_{2}\right)$ was not modulated by glucagon. Furthermore, the respective normoxia responsive elements in the SerDH promoter were identified and characterized. 
А. А. Самойленко, Н. Н. Теплюк, М. Ю. Оболенская,

\section{T. Китимманн}

Кислород в межклеточном пространстве гепатоцитов как регулятор транскрипции гена сериндегидратазы.

Резюме

В связи с однонаправленным движением крови от портальной вены и печеночной артерии киентральной вене и из-за использования кислорода клетками синусоида в печени формируется градиент концентрации кислорода. Его различные концентраичи определяют неравномерную экспрессию генов в клетках, расположенных в перипортальной и перивенозной зонах печеночного синусоида. Ген, кодирующий сериндегидратазу (СДГ), является типичным представителем генов, преимущественно экспрессируюшихся в гепатоичтах перипортальной зоны синусоида. Нозерн-блот гибридизация и трансфекиия первичных гепатоцитов крысы конструкиией, содержащей репортерный ген лючиферазы под контролем промотора гена СДГ (-2303 ...+55 n. н.), выявили, что экспрессия СДГ выше при нормоксии $\left(16 \% \mathrm{O}_{2}\right)$, чем при гипоксии (8\% $\left.\mathrm{O}_{2}\right)$. Четыре потенцииальных элемента ответа на нормоксию (ЭОН) обнаружены в промоторе гена СДГ (ЭОН-1, ЭОН-2, ЭОН-3 и ЭОН-4). Чтобы установить, какой из этих элементов функционирует в гепатоцитах, клетки трансфицировали конструкциями с репортерным геном люииферазы, находящимся под контролем в разной мере укороченных участков промотора гена СДГ. Tрансфекиия клеток HeLa и HepG2 конструкииями, содержащими шесть последовательно расположенных копий каждого из потенииальных ЭОН перед промотором SV40 и репортерным геном люииферазы, показала, что ЭОН-2 в клетках HeLa u Hep G2, а ЭОН-1 в клетках HeLa участвуют в регуляции транскрипиии гена СДГ при нормоксии.

Ключевые слова: ген сериндегидратазы, регулячия транскрипиии, репортерный ген, люичиераза, гепатоциты, нормоксия.

\section{REFERENCES}

1. Jungermann K., Kietzmann T. Oxygen: modulator of metabolic zonation and disease of the liver // Hepatology.-2000.-31.-P. 255-260.

2. Semenza G. L. Regulation of physiological responses to continuous and intermittent hypoxia by hypoxia-inducible factor 1 // Exp. Physiol.-2006.-91.-P. 803-806.

3. Cowan D. B., Weisel R. D., Williams W. G., Mickle D. A. G. Identification of oxygen responsive elements in the 5 '-flanking region of the human glutathione-peroxidase gene // J. Biol. Chem.-1993.-268.-P. 26904-26910.

4. Bratke J., Kietzmann T., Jungermann K. Identification of an oxygen responsive element in the 5 '-flanking sequence of the rat cytosolic phosphoenolpyruvate carboxykinase-1 gene, modulating its glucagon-dependent activation // Biochem. J.-1999.-339.-P. 563-569.

5. Merante F., Altamentova S. M., Mickle D. A. G., Weisel R. D., Thatcher B. J., Martin B. M., Marshall J. G., Tumati L. C.,
Cowan D. B., Li R. K. The characterization and purification of a human transcription factor modulating the glutathione peroxidase gene in response to oxygen tension // Mol. and Cell. Biochem.-2002.-229.-P. 73-83.

6. Ogawa H., Fujioka M., Matsuda Y., Su Y., Dunn T., Miller D. A., Pitot H. C. Sequence of the rat serine dehydratase gene // Nucl. Acids Res.-1988.-16.-P. 10921-10923.

7. Su Y., Kanamoto R., Miller D. A., Ogawa H., Pitot H. C. Regulation of the expression of the serine dehydratase gene in the kidney and liver of the rat // Biochem. and Biophys. Res. Communs.-1990.-170.-P. 892-899.

8. Berry M. N., Friend D. S. High-yield preparation of isolated rat liver parenchymal cells - A biochemical and fine structural study // J. Cell Biol.-1969.-43.-P. 506-520.

9. Kietzmann T., Cornesse Y., Brechtel K., Modaressi S., Jungermann $K$. Perivenous expression of the mRNA of the three hypoxia-inducible factor alpha-subunits, HIF1alpha, HIF2alpha and HIF3alpha, in rat liver // Biochem. J.-2001.-354.-P. 531-537.

10. Immenschuh S., Hinke V., Ohlmann A., Gifhorn-Katz S., Katz $N$., Jungermann K., Kietzmann T. Transcriptional activation of the haem oxygenase- 1 gene by cGMP via a cAMP response element/activator protein-1 element in primary cultures of rat hepatocytes // Biochem. J.-1998.-334.-P. 141-146.

11. Samoylenko A., Roth U., Jungermann K., Kietzmann T. The upstream stimulatory factor-2a inhibits plasminogen activator inhibitor-1 gene expression by binding to a promoter element adjacent to the hypoxia-inducible factor-1 binding site // Blood.-2001.-97.-P. 2657-2666.

12. Haas M. J., Pitot H. C. Glucocorticoids stimulate CREB binding to a cyclic-AMP response element in the rat serine dehydratase gene // Arch. Biochem. and Biophys.1999.-362.-P. 317-324.

13. Harris A. L. Hypoxia - a key regulatory factor in tumor growth // Nat. Revs Cancer.-2001.-2.-P. 38-46.

14. Semenza G. L. Targeting HIF-1 for cancer therapy // Nat. Revs Cancer.-2003.-3.-P. 721-732.

15. Pinsky D. J., Liao H., Lawson C. A., Yan S. F., Chen J., Carmeliet P., Loskutoff D. J., Stern D. M. Coordinated induction of plasminogen activator inhibitor-1 (PAI-1) and inhibition of plasminogen activator gene expression by hypoxia promotes pulmonary vascular fibrin deposition // J. Clin. Invest.-1998.-102.-P. 919-928.

16. Pillay $V$., Dass C. R., Choong $P . F$. The urokinase plasminogen activator receptor as a gene therapy target for cancer // Trends Biotechnol.-2007.-25.-P. 33-39.

17. Narravula $S$., Colgan $S$. $P$. Hypoxia-inducible factor 1-mediated inhibition of peroxisome proliferator-activated receptor alpha expression during hypoxia // J. Immunol.-2001.-166.-P. 7543-7548.
UDC 577.218

Received 22.05.07 